\title{
Enterovesical Fistula
}

National Cancer Institute

\section{Source}

National Cancer Institute. Enterovesical Fistula. NCI Thesaurus. Code C78266.

An abnormal communication between the urinary bladder and the intestine. 